\title{
Anti-Inflammatory Effects of Flavonoids: Genistein, Kaempferol, Quercetin, and Daidzein Inhibit STAT-1 and NF- $\kappa$ B Activations, Whereas Flavone, Isorhamnetin, Naringenin, and Pelargonidin Inhibit only NF- $\kappa$ B Activation along with Their Inhibitory Effect on iNOS Expression and NO Production in Activated Macrophages
}

\author{
Mari Hämäläinen, ${ }^{1}$ Riina Nieminen, ${ }^{1}$ Pia Vuorela, ${ }^{2}$ Marina Heinonen, ${ }^{3}$ and Eeva Moilanen ${ }^{1}$ \\ ${ }^{1}$ The Immunopharmacology Research Group, University of Tampere, Medical School and Tampere University Hospital, \\ Research Unit, 33014 Tampere, Finland \\ ${ }^{2}$ Department of Biochemistry and Pharmacy, Åbo Akademi University, 20520 Turku, Finland \\ ${ }^{3}$ Department of Applied Chemistry and Microbiology, University of Helsinki, 00014 Helsinki, Finland
}

Correspondence should be addressed to Eeva Moilanen, eeva.moilanen@uta.fi

Received 18 December 2006; Revised 16 March 2007; Accepted 26 April 2007

In inflammation, bacterial products and proinflammatory cytokines induce the formation of large amounts of nitric oxide (NO) by inducible nitric oxide synthase (iNOS), and compounds that inhibit NO production have anti-inflammatory effects. In the present study, we systematically investigated the effects of 36 naturally occurring flavonoids and related compounds on NO production in macrophages exposed to an inflammatory stimulus (lipopolysaccharide, LPS), and evaluated the mechanisms of action of the effective compounds. Flavone, the isoflavones daidzein and genistein, the flavonols isorhamnetin, kaempferol and quercetin, the flavanone naringenin, and the anthocyanin pelargonidin inhibited iNOS protein and mRNA expression and also NO production in a dose-dependent manner. All eight active compounds inhibited the activation of nuclear factor- $\kappa \mathrm{B}(\mathrm{NF}-\kappa \mathrm{B})$, which is a significant transcription factor for iNOS. Genistein, kaempferol, quercetin, and daidzein also inhibited the activation of the signal transducer and activator of transcription 1 (STAT-1), another important transcription factor for iNOS. The present study characterises the effects and mechanisms of naturally occurring phenolic compounds on iNOS expression and NO production in activated macrophages. The results partially explain the pharmacological efficacy of flavonoids as anti-inflammatory compounds.

Copyright (C) 2007 Mari Hämäläinen et al. This is an open access article distributed under the Creative Commons Attribution License, which permits unrestricted use, distribution, and reproduction in any medium, provided the original work is properly cited.

\section{INTRODUCTION}

Nitric oxide $(\mathrm{NO})$ is produced from L-arginine by three nitric oxide synthase (NOS) enzymes; endothelial NOS (eNOS), neuronal NOS (nNOS), and inducible NOS (iNOS). Low physiological levels of NO are produced by constitutively expressed eNOS and nNOS, whereas iNOS is responsible for prolonged production of larger amounts of NO. iNOS is induced by bacterial products and inflammatory cytokines in macrophages and some other cells [1-3]. NO production is increased in inflammation and has proinflammatory and regulatory effects $[4,5]$. In addition, peroxynitrite formation in a reaction of $\mathrm{NO}$ and superoxide may lead to increased cy- totoxicity. The experimental data support the idea that compounds inhibiting expression or activity of iNOS are potential anti-inflammatory agents [6-9].

Flavonoids are naturally occurring polyphenolic compounds containing two benzene rings linked together with a heterocyclic pyran or pyrone ring. Flavonoids are normal constituents of the human diet and are known for a variety of biological activities. Some of these act as enzyme inhibitors and antioxidants, and have been reported to have anti-inflammatory properties. However, the molecular mechanisms explaining how flavonoids suppress the inflammatory response are not known in detail $[10,11]$. There are studies showing that certain flavonoids down-regulate NO 
production in response to inflammatory stimuli [12-14], but no more precise mechanisms of action are known.

In the present study, we investigated the effects of 36 naturally occurring compounds representing different groups of flavonoids and related compounds on iNOS expression and NO production in activated macrophages systematically, and evaluated the mechanisms of action of the effective compounds.

\section{MATERIALS AND METHODS}

\subsection{Materials}

Luteolin, luteolin-7-glucoside, vitexin, daidzein, genistein, genistin, rhamnetin, isorhamnetin, kaempferol, myricetin, taxifolin, naringin, ferulic acid, pelargonidin, procyanidin B1, and procyanidin B2 were obtained from Extrasynthese (Lyon, France). Acacetin, cyanidin, flavone, morin, and quercitrin were obtained from Carl Roth GmbH (Karlsruhe, Germany). Quercetin, rutin, and benzoic acid were obtained from Merck (Darmstadt, Germany). Naringenin, +catechin, - epicatechin, ellagic acid, gallic acid, and syringic acid were obtained from Sigma (St. Louis, MO, USA). Apigenin, chlorogenic acid, dodecyl gallate, methyl gallate, octyl gallate, and sinapic acid were obtained from Fluka (Buchs SG, Switzerland).

Dulbecco's modified eagle medium and its supplements were obtained from Gibco BRL (Paisley, UK). All other reagents were obtained from Sigma (St. Louis, MO, USA) unless otherwise stated.

\subsection{Cell culture}

Murine J774 macrophages were obtained from American Type Culture Collection (Rockville, MD, U.S.A). Cells were cultured at $37^{\circ} \mathrm{C}$ (in $5 \%$ carbon dioxide) in Dulbecco's modified eagle's medium (DMEM) with glutamax-I containing 10\% heat-inactivated foetal bovine serum, penicillin (100 units/ml), streptomycin $(100 \mu \mathrm{g} / \mathrm{ml})$, and amphotericin $\mathrm{B}(250 \mathrm{ng} / \mathrm{ml})$. Cells were harvested with trypsin-EDTA. Cells were seeded in 96-well plates for XTT-test, in 24-well plates for nitrite measurements, in 6-well plates for iNOS Western blot and RNA extraction, and in 10-cm dishes for p65 and STAT- $1 \alpha$ Western blot. Confluent cells were exposed to fresh culture medium containing the compounds of interest and cultured for the times indicated.

\subsection{XTT-test}

Cell viability was tested using cell proliferation kit II that measures the cells' ability to metabolize XTT to formazan by mitochondrial dehydrogenase activity, a function that only occurs in viable cells (Roche Diagnostics $\mathrm{GmbH}$, Mannhein, Germany). Cells were incubated with the tested compounds and LPS for 20 hours before addition of sodium 3'-[1-(phenylaminocarbonyl)-3,4-tetrazolium]bis (4-methoxy-6-nitro) benzene sulphonic acid hydrate (XTT) (final concentration $0.3 \mathrm{mg} / \mathrm{ml}$ ) and N-methyl dibenzopyrazine methyl sulphate $(8.2 \mu \mathrm{M})$. Cells were incubated for another 4 hours and the amount of formazan accumulating in growth medium was assessed spectrophotometrically. Triton-X treated cells were used as a positive control. Conditions were considered nontoxic if the cells' ability to metabolize XTT to formazan was more than $80 \%$ of that of cells exposed to LPS only.

\subsection{Nitrite determinations}

Measurement of nitrite accumulation into the culture medium was used to determine $\mathrm{NO}$ production. At the indicated time points, the culture medium was collected and nitrite was measured by the Griess reaction [15]. A NOS inhibitor L-NIO (1 mM) and a highly selective iNOS inhibitor $1400 \mathrm{~W}(1 \mathrm{mM})$ were added at the beginning of the incubation to cells that were stimulated with LPS $(100 \mathrm{ng} / \mathrm{ml})$ to ensure that the measured nitrite was due to $\mathrm{NO}$ produced by the iNOS pathway in the cell culture.

\subsection{Preparation of cell lysates for iNOS Western blot}

After the desired time of incubation cell lysates were prepared as described earlier [16]. The Coomassie blue method was used to measure the protein content of the samples [17].

\subsection{Preparation of nuclear extracts for p65 and STAT-1 $\alpha$ Western blot}

Cells were seeded on $10-\mathrm{cm}$ dishes and were grown to confluence. Cells were incubated with the compounds of interest for 30 minutes (p65) or for 6 hours (STAT-1 $\alpha$ ). After incubation, samples were prepared as described earlier [18]. The Coomassie blue method was used to measure the protein content of the samples [17].

\subsection{Western blot analysis of iNOS, p65, and STAT-1 $\alpha$ proteins}

Protein samples $(20 \mu \mathrm{g})$ were separated by SDS-PAGE on $8 \%$ polyacrylamide gel and transferred to nitrocellulose membrane. Bound antibody (rabbit polyclonal antibodies for iNOS, STAT- $1 \alpha$ (Santa Cruz Biotechnology, Santa Cruz, CA, USA), or for p65 subunit of NF- $\kappa$ B (Cell Signaling Danvers, MA, USA)) was detected using goat anti-rabbit polyclonal antibody (Santa Cruz Biotechnology, Santa Cruz, CA, USA), and visualised by SuperSignal chemiluminescent substrate (Pierce, Cheshire, UK) and FluorChem 8800 imaging system (Alpha Innotech Corporation, San Leandro, CA). The quantitation of the chemiluminescent signal was carried out using FluorChem software version 3.1.

\subsection{RNA extraction and real-time RT-PCR of iNOS and GAPDH mRNAs}

J774 cells stimulated with the compounds of interest were trypsinised after the desired time of incubation. Cell homogenization, RNA extraction, reverse transcription, and quantitative PCR were performed as described earlier [16]. The primer and probe sequences and concentrations were 


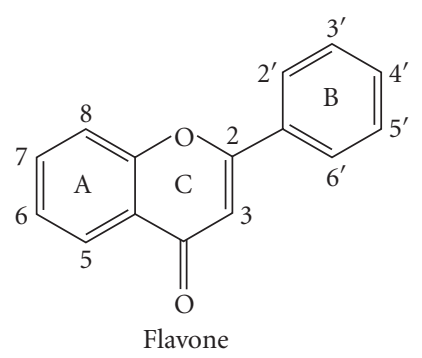<smiles>O=c1c(-c2ccccc2)coc2ccccc12</smiles><smiles>O=c1c(O)c(-c2ccccc2)oc2ccccc12</smiles><smiles>O=C1CC(c2ccccc2)Oc2ccccc21</smiles>

Flavanone<smiles>OC1Cc2ccccc2OC1c1ccccc1</smiles>

Flavan-3-ol<smiles>Oc1cc2ccccc2[o+]c1-c1ccccc1</smiles><smiles>O=C(O)/C=C\c1ccc(O)cc1</smiles>

HBA

HCA

FIgURE 1: Basic chemical structures of the phenolic compounds used in the present study.

optimized according to the manufacturer's instructions in TaqMan Universal PCR Master Mix Protocol part number 4304449 revision $\mathrm{C}$ and were as follows: 5'-CCTGGTACGGGCATTGCT-3', 5'-GCTCATGCGGCCTCCTT3', (forward and reverse mouse iNOS primers, resp., both $300 \mathrm{nM}$ ), 5'-CAGCAGCGGCTCCATGACTCCC-3' (mouse iNOS probe containing 6-FAM as $5^{\prime}$-reporter dye and TAMRA as 3'-quencher, $150 \mathrm{nM}$ ), 5'-GCATGGCCTTCCGTGTTC-3', 5'-GATGTCATCATACTTGGCAGGTTT-3' (forward and reverse mouse glyceraldehyde-3-phosphate dehydrogenase (GAPDH) primers, resp., both $300 \mathrm{nM}$ ), 5'-TCGTGGATCTGACGTGCCGCC-3' (mouse GAPDH probe containing 6-FAM as 5'-reporter dye and TAMRA as 3'quencher, $150 \mathrm{nM})$. Results of iNOS mRNA levels were normalized against GAPDH mRNA in each sample.

\subsection{Statistics}

Results are expressed as mean \pm standard error of mean (SEM). The statistical significance of the detected differences was calculated by analysis of variance followed by Dunnett multiple comparison's test. Differences were considered significant when $P<.05$.

\section{RESULTS}

The tested compounds $(n=36)$ represented eight groups of flavonoids and related compounds: flavones, isoflavones, flavonols, flavanones, flavan-3-ols, anthocyanins, hydroxybenzoic acid (HBA) group, and hydroxycinnamic acid (HCA) group. The tested compounds are listed and their structures are shown in Figure 1 and Table 1.Possible cytotoxic effects were tested by XTT-test. Compounds that were toxic at $100 \mu \mathrm{M}$ (see Table 2) were excluded from further studies.

\subsection{Effects of flavonoids on LPS-induced NO production in $\mathrm{J774}$ cells}

Untreated J774 macrophages did not produce detectable amounts of NO during 24-hour incubation, but LPS ( $100 \mathrm{ng} / \mathrm{ml}$ ) enhanced NO production significantly. In the first experiments, flavonoids were used at $10 \mu \mathrm{M}$ and $100 \mu \mathrm{M}$ concentrations. The compounds inhibiting NO production by more than $50 \%$ at $100 \mu \mathrm{M}$ concentration compared to LPS-treated control were flavone, daidzein, genistein, isorhamnetin, kaempferol, quercetin, naringenin, and pelargonidin (see Table 2). NOS inhibitor L-NIO (1 mM) and a selective iNOS inhibitor $1400 \mathrm{~W}(1 \mathrm{mM})$ were used as control compounds, and they inhibited LPS-induced NO production by more than $90 \%$.

If the compound inhibited $\mathrm{NO}$ production by more than $50 \%$ at $100 \mu \mathrm{M}$ concentration, a dose-response effect was studied. All eight active compounds (flavone, daidzein, genistein, isorhamnetin, kaempferol, quercetin, naringenin, 
TABLE 1: Chemical structures of the phenolic compounds used in the present study.

\begin{tabular}{|c|c|c|c|c|c|c|c|c|c|}
\hline \multirow{2}{*}{ Class } & \multirow{2}{*}{ Derivatives } & \multicolumn{8}{|c|}{ Substituents } \\
\hline & & $1^{*}$ & 3 & 5 & 7 & $3^{\prime}$ & $4^{\prime}$ & $5^{\prime}$ & \\
\hline \multirow{6}{*}{ Flavones } & Acacetin & & $\mathrm{H}$ & $\mathrm{OH}$ & $\mathrm{OH}$ & $\mathrm{H}$ & $\mathrm{OCH}_{3}$ & $\mathrm{H}$ & \\
\hline & Apigenin & & $\mathrm{H}$ & $\mathrm{OH}$ & $\mathrm{OH}$ & $\mathrm{H}$ & $\mathrm{OH}$ & $\mathrm{H}$ & \\
\hline & Flavone & & $\mathrm{H}$ & $\mathrm{H}$ & $\mathrm{H}$ & $\mathrm{H}$ & $\mathrm{H}$ & $\mathrm{H}$ & \\
\hline & Luteolin & & $\mathrm{H}$ & $\mathrm{OH}$ & $\mathrm{OH}$ & $\mathrm{OH}$ & $\mathrm{OH}$ & $\mathrm{H}$ & \\
\hline & Lut-7-glucoside & & $\mathrm{H}$ & $\mathrm{OH}$ & OGlc & $\mathrm{OH}$ & $\mathrm{OH}$ & $\mathrm{H}$ & \\
\hline & Vitexin & & $\mathrm{H}$ & $\mathrm{OH}$ & $\mathrm{OH}$ & $\mathrm{H}$ & $\mathrm{OH}$ & $\mathrm{H}$ & $8 \mathrm{Glc}$ \\
\hline \multirow{3}{*}{ Isoflavones } & Daidzein & & $\mathrm{H}$ & $\mathrm{H}$ & $\mathrm{OH}$ & $\mathrm{H}$ & $\mathrm{OH}$ & $\mathrm{H}$ & \\
\hline & Genistein & & $\mathrm{H}$ & $\mathrm{OH}$ & $\mathrm{OH}$ & $\mathrm{H}$ & $\mathrm{OH}$ & $\mathrm{H}$ & \\
\hline & Genistin & & $\mathrm{H}$ & $\mathrm{OH}$ & OGlc & $\mathrm{H}$ & $\mathrm{OH}$ & $\mathrm{H}$ & \\
\hline \multirow{8}{*}{ Flavonols } & Isorhamnetin & & $\mathrm{OH}$ & $\mathrm{OH}$ & $\mathrm{OH}$ & $\mathrm{OCH}_{3}$ & $\mathrm{OH}$ & $\mathrm{H}$ & \\
\hline & Kaempferol & & $\mathrm{OH}$ & $\mathrm{OH}$ & $\mathrm{OH}$ & $\mathrm{H}$ & $\mathrm{OH}$ & $\mathrm{H}$ & \\
\hline & Morin & & $\mathrm{OH}$ & $\mathrm{OH}$ & $\mathrm{OH}$ & $\mathrm{H}$ & $\mathrm{OH}$ & $\mathrm{H}$ & 2' $\mathrm{OH}$ \\
\hline & Myricetin & & $\mathrm{OH}$ & $\mathrm{OH}$ & $\mathrm{OH}$ & $\mathrm{OH}$ & $\mathrm{OH}$ & $\mathrm{OH}$ & \\
\hline & Quercetin & & $\mathrm{OH}$ & $\mathrm{OH}$ & $\mathrm{OH}$ & $\mathrm{OH}$ & $\mathrm{OH}$ & $\mathrm{H}$ & \\
\hline & Quercitrin & & ORha & $\mathrm{OH}$ & $\mathrm{OH}$ & $\mathrm{OH}$ & $\mathrm{OH}$ & $\mathrm{H}$ & \\
\hline & Rhamnetin & & $\mathrm{OH}$ & $\mathrm{OH}$ & $\mathrm{OCH}_{3}$ & $\mathrm{OH}$ & $\mathrm{OH}$ & $\mathrm{H}$ & \\
\hline & Rutin & & $\mathrm{ORu}$ & $\mathrm{OH}$ & $\mathrm{OH}$ & $\mathrm{OH}$ & $\mathrm{OH}$ & $\mathrm{H}$ & \\
\hline \multirow{3}{*}{ Flavanones } & Naringenin & & $\mathrm{H}$ & $\mathrm{OH}$ & $\mathrm{OH}$ & $\mathrm{H}$ & $\mathrm{OH}$ & $\mathrm{H}$ & \\
\hline & Naringin & & $\mathrm{H}$ & $\mathrm{OH}$ & ONeo & $\mathrm{H}$ & $\mathrm{OH}$ & $\mathrm{H}$ & \\
\hline & Taxifolin & & $\mathrm{OH}$ & $\mathrm{OH}$ & $\mathrm{OH}$ & $\mathrm{OH}$ & $\mathrm{OH}$ & $\mathrm{H}$ & \\
\hline \multirow{4}{*}{ Flavan-3-ols } & +Catechin & & $\mathrm{OH}$ & $\mathrm{OH}$ & $\mathrm{OH}$ & $\mathrm{OH}$ & $\mathrm{OH}$ & $\mathrm{H}$ & \\
\hline & -Epicatechin & & $\mathrm{OH}\|\|\|\|$ & $\mathrm{OH}$ & $\mathrm{OH}$ & $\mathrm{OH}$ & $\mathrm{OH}$ & $\mathrm{H}$ & \\
\hline & Procyanidin B1 & & Dimer o & picatech & a catec & inked vis & ir carbo & and & spectively. \\
\hline & Procyanidin B2 & & Dimer o & No epica & in mole & linked v & arbons 4 & 8 & \\
\hline \multirow{2}{*}{ Anthocyanins } & Cyanidin & & $\mathrm{OH}$ & $\mathrm{OH}$ & $\mathrm{OH}$ & $\mathrm{OH}$ & $\mathrm{OH}$ & $\mathrm{H}$ & \\
\hline & Pelargonidin & & $\mathrm{OH}$ & $\mathrm{OH}$ & $\mathrm{OH}$ & $\mathrm{H}$ & $\mathrm{OH}$ & $\mathrm{H}$ & \\
\hline \multirow{7}{*}{ HBA } & Benzoic acid & & $\mathrm{H}$ & $\mathrm{H}$ & & & & & $4 \mathrm{H}$ \\
\hline & Dodecyl gallate & $\mathrm{COO}\left(\mathrm{CH}_{2}\right)_{11} \mathrm{CH}_{3}$ & $\mathrm{OH}$ & $\mathrm{OH}$ & & & & & \\
\hline & Ellagic acid & see below & & & & & & & \\
\hline & Gallic acid & & $\mathrm{OH}$ & $\mathrm{OH}$ & & & & & \\
\hline & Methyl gallate & $\mathrm{COOCH}_{3}$ & $\mathrm{OH}$ & $\mathrm{OH}$ & & & & & \\
\hline & Octyl gallate & $\mathrm{COOCH}_{2}\left(\mathrm{CH}_{2}\right)_{6} \mathrm{CH}_{3}$ & $\mathrm{OH}$ & $\mathrm{OH}$ & & & & & \\
\hline & Syringic acid & & $\mathrm{OCH}_{3}$ & $\mathrm{OCH}_{3}$ & & & & & \\
\hline \multirow{3}{*}{ HCA } & Chlorogenic acid & see below & & & & & & & \\
\hline & Ferulic acid & & $\mathrm{OCH}_{3}$ & & & & & & \\
\hline & Sinapic acid & & $\mathrm{OCH}_{3}$ & $\mathrm{OCH}_{3}$ & & & & & \\
\hline
\end{tabular}

* if other than in basic structure

Glc=glycoside, Rha=rhamnoside, $\mathrm{Ru}=$ rutinoside, $\mathrm{Neo}=$ neohesperidoside

OH group is in front of plane of paper, |llimm. $\mathrm{OH}$ group is behind plane of paper<smiles></smiles>

Ellagic acid<smiles>O=C(/C=C/c1ccc(O)c(O)c1)OC1CC(O)(C(=O)O)CC(O)C1O</smiles>

Chlorogenic acid 
TABLE 2: Effects of phenolic compounds on cell viability and on LPS-induced ( $100 \mathrm{ng} / \mathrm{ml})$ NO production in J774 macrophages. No detectable NO production was found in untreated cells. Mean \pm standard error of mean (SEM).

\begin{tabular}{|c|c|c|c|}
\hline \multirow{2}{*}{$\begin{array}{l}\text { Class } \\
\text { Derivatives }\end{array}$} & \multirow{2}{*}{$\begin{array}{l}\text { Toxicity } \\
{[100 \mu \mathrm{M}]}\end{array}$} & \multicolumn{2}{|c|}{ NO production (inhibition\%) } \\
\hline & & {$[10 \mu \mathrm{M}]$} & {$[100 \mu \mathrm{M}]$} \\
\hline LPS $100 \mathrm{ng} / \mathrm{ml}$ & & 0 & 0 \\
\hline \multicolumn{4}{|l|}{ Flavones } \\
\hline Acacetin & + & & \\
\hline Apigenin & + & & \\
\hline Flavone & - & $20.4 \pm 1.7$ & $92.8 \pm 0.6$ \\
\hline Luteolin & + & & \\
\hline Luteolin-7-glucoside & - & $3.1 \pm 1.7$ & $38.6 \pm 1.1$ \\
\hline Vitexin & - & $-1.9 \pm 0.8$ & $6.2 \pm 0.7$ \\
\hline \multicolumn{4}{|l|}{ Isoflavones } \\
\hline Daidzein & - & $11.3 \pm 6.3$ & $70.3 \pm 3.1$ \\
\hline Genistein & - & $11.6 \pm 2.4$ & $97.4 \pm 0.2$ \\
\hline Genistin & - & $9.7 \pm 2.1$ & $13.3 \pm 2.0$ \\
\hline \multicolumn{4}{|l|}{ Flavonols } \\
\hline Isorhamnetin & - & $3.5 \pm 0.9$ & $65.1 \pm 1.6$ \\
\hline Kaempferol & - & $8.4 \pm 2.2$ & $99.6 \pm 0.2$ \\
\hline Morin & - & $4.8 \pm 1.3$ & $40.8 \pm 2.4$ \\
\hline Myricetin & - & $-0.6 \pm 2.6$ & $32.3 \pm 2.8$ \\
\hline Quercetin & - & $-1.5 \pm 5.1$ & $89.7 \pm 0.3$ \\
\hline Quercitrin & - & $5.1 \pm 0.8$ & $19.1 \pm 0.8$ \\
\hline Rhamnetin & + & & \\
\hline Rutin & - & $-2.2 \pm 2.0$ & $8.7 \pm 1.0$ \\
\hline \multicolumn{4}{|l|}{ Flavanones } \\
\hline Naringenin & - & $14.7 \pm 1.3$ & $59.6 \pm 3.3$ \\
\hline Naringin & - & $1.9 \pm 2.5$ & $3.9 \pm 2.1$ \\
\hline Taxifolin & - & $3.1 \pm 1.8$ & $23.9 \pm 1.8$ \\
\hline \multicolumn{4}{|l|}{ Flavan-3-ols } \\
\hline + Catechin & + & & \\
\hline - Epicatechin & - & $-0.6 \pm 1.8$ & $-0.1 \pm 1.0$ \\
\hline Procyanidin B1 & - & $-8.4 \pm 1.4$ & $-2.2 \pm 1.9$ \\
\hline Procyanidin B2 & - & $-0.6 \pm 2.5$ & $0.8 \pm 1.7$ \\
\hline \multicolumn{4}{|l|}{ Anthocyanins } \\
\hline Cyanidin & - & $-4.9 \pm 3.8$ & $5.3 \pm 1.8$ \\
\hline Pelargonidin & - & $4.5 \pm 1.1$ & $59 \pm 0.8$ \\
\hline \multicolumn{4}{|l|}{ HBA $^{(b)}$} \\
\hline Benzoic acid & - & $0.7 \pm 2.0$ & $-4.0 \pm 1.5$ \\
\hline Dodecyl gallate & + & & \\
\hline Ellagic acid & - & $-15.1 \pm 3.0$ & $38.2 \pm 1.9$ \\
\hline Gallic acid & + & & \\
\hline Methyl gallate & - & $11.2 \pm 0.9$ & $30.5 \pm 1.0$ \\
\hline Octyl gallate & + & & \\
\hline Syringic acid & - & $6.7 \pm 1.5$ & $5.1 \pm 1.6$ \\
\hline \multicolumn{4}{|l|}{$\mathrm{HCA}^{(\mathrm{c})}$} \\
\hline Chlorogenic acid & - & $-4.8 \pm 3.5$ & $-0.9 \pm 2.0$ \\
\hline Ferulic acid & - & $6.6 \pm 1.1$ & $9.0 \pm 1.5$ \\
\hline \multirow[t]{2}{*}{ Sinapic acid } & - & $8.9 \pm 1.9$ & $5.2 \pm 1.3$ \\
\hline & $n=6$ & $n=6$ & $n=6$ \\
\hline
\end{tabular}

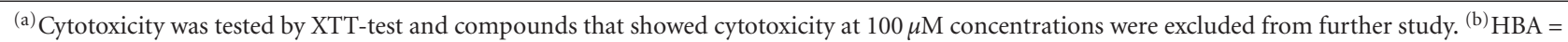
hydroxybenzoic acid, ${ }^{(c)} \mathrm{HCA}=$ hydroxycinnamic acid, $\mathrm{n}=$ number of replicates. 
and pelargonidin) inhibited $\mathrm{NO}$ production in a dosedependent manner in the following order: quercetin $\left(\mathrm{IC}_{50} \sim\right.$ $25 \mu \mathrm{M}) \sim$ kaempferol $\left(\mathrm{IC}_{50} \sim 25 \mu \mathrm{M}\right)>$ genistein $\left(\mathrm{IC}_{50} \sim\right.$ $30 \mu \mathrm{M}) \sim$ isorhamnetin $\left(\mathrm{IC}_{50} \sim 30 \mu \mathrm{M}\right)>$ flavone $\left(\mathrm{IC}_{50} \sim\right.$ $40 \mu \mathrm{M})>$ daidzein $\left(\mathrm{IC}_{50} \sim 70 \mu \mathrm{M}\right)>$ naringenin $\left(\mathrm{IC}_{50} \sim\right.$ $80 \mu \mathrm{M})>$ pelargonidin $\left(\mathrm{IC}_{50} \sim 90 \mu \mathrm{M}\right)$ (see Figure 2 ).

\subsection{Effects of flavonoids on LPS-induced iNOS protein expression}

The effects of those eight flavonoids inhibiting NO production by more than $50 \%$ at $100 \mu \mathrm{M}$ concentrations were tested on iNOS protein expression by Western blot analysis. Unstimulated cells did not express detectable amounts of iNOS protein and LPS enhanced iNOS protein expression considerably. All eight active compounds (flavone, daidzein, genistein, isorhamnetin, kaempferol, quercetin, naringenin, and pelargonidin) inhibited LPS-induced iNOS protein expression (see Figure 3).

\subsection{Effects of flavonoids on LPS-induced iNOS mRNA levels}

iNOS mRNA was measured by quantitative real-time RTPCR. Cells were incubated with LPS $(100 \mathrm{ng} / \mathrm{ml})$ or with LPS and the tested flavonoid (flavone, daidzein, genistein, isorhamnetin, kaempferol, quercetin, naringenin, or pelargonidin $(100 \mu \mathrm{M}))$ for 6 hours. This incubation time was chosen according to the time curve of iNOS mRNA, where the maximal iNOS mRNA levels were between 6 and 8 hours after addition of LPS. Untreated cells expressed very low levels of iNOS mRNA and LPS enhanced iNOS mRNA expression considerably. All eight tested flavonoids significantly lowered iNOS mRNA levels when measured after 6hour incubation in the following order of potency: quercetin $>$ kaempferol $>$ genistein $>$ isorhamnetin $>$ flavone $>$ naringenin $>$ daidzein $\sim$ pelargonidin (see Figure 4 ).

\subsection{Effects of flavonoids on LPS-induced activation of transcription factors NF- $\kappa$ B and STAT- 1}

NF- $\kappa \mathrm{B}$ and STAT-1 are important transcription factors for iNOS $[19,20]$. Therefore we measured the effects of the eight effective flavonoids on NF- $\kappa \mathrm{B}$ and STAT- 1 activations by measuring the nuclear translocation of the factors by Western blot.

In unstimulated cells, low basal activity of NF- $\kappa$ B was detected and was significantly enhanced after LPS challenge. The maximal activation was found 30 minutes after LPS addition, and that incubation time was used in the subsequent studies. Quercetin, naringenin and pelargonidin inhibited the LPS-induced activation of NF- $\kappa$ B by more than $80 \%$. Flavone, genistein, isorhamnetin, kaempferol, and daidzein had a moderate $(57 \%-72 \%$ inhibition) inhibitory effect (see Figure 5).

Nuclear STAT-1 levels were significantly enhanced after LPS challenge. The maximal effect was found 6 hours after LPS addition, and that time point was chosen for subsequent studies. The LPS-induced activity of STAT-1 was nearly

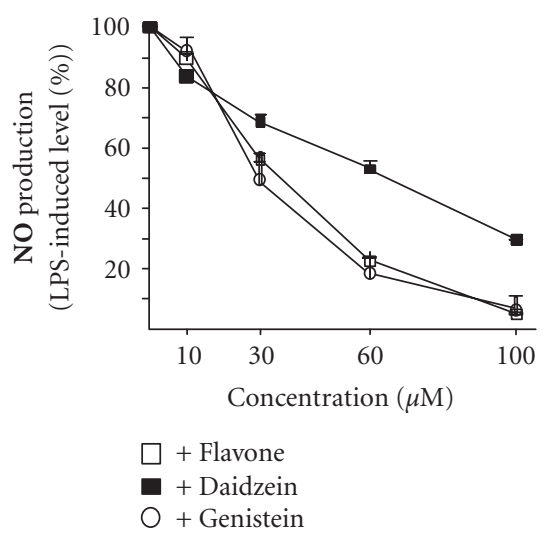

(a)

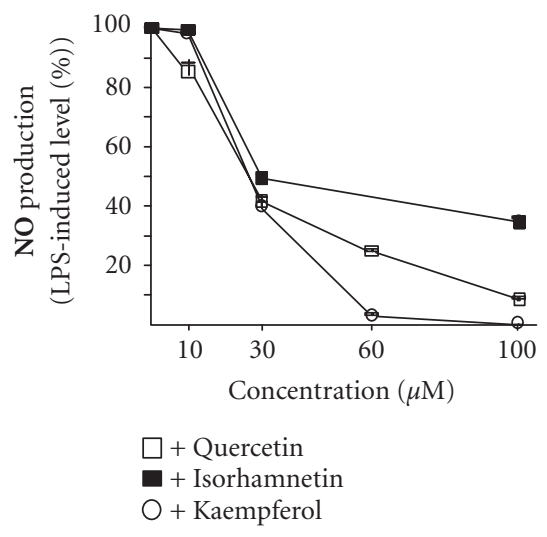

(b)

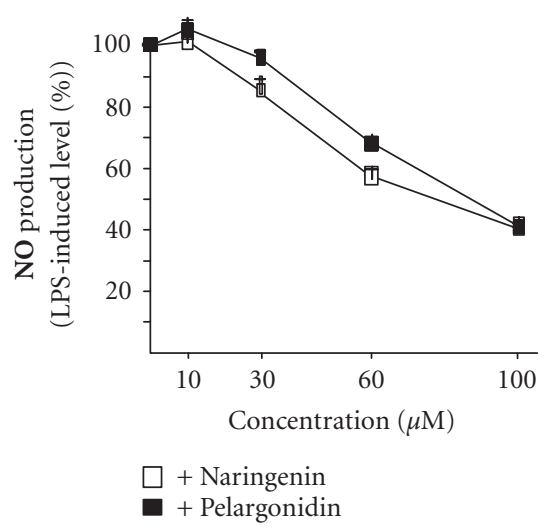

(c)

Figure 2: (a) Effects of increasing concentrations of flavone, daidzein, and genistein on LPS $(100 \mathrm{ng} / \mathrm{ml})$-induced NO production in J774 cells during a 24-hour incubation time. (b) Effects of increasing concentrations of quercetin, isorhamnetin, and kaempferol on LPS (100 ng/ml)-induced NO production in J774 cells during a 24-hour incubation time. (c) Effects of increasing concentrations of naringenin and pelargonidin on LPS $(100 \mathrm{ng} / \mathrm{ml})$-induced NO production in J774 cells during a 24-hour incubation time. NO production was determined by measuring nitrite accumulation in the culture medium by Griess reaction. Mean + SEM, $n=6$. 


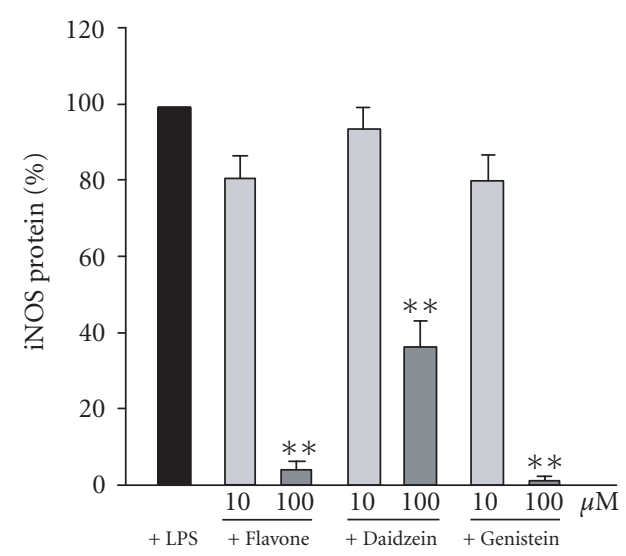

(a)

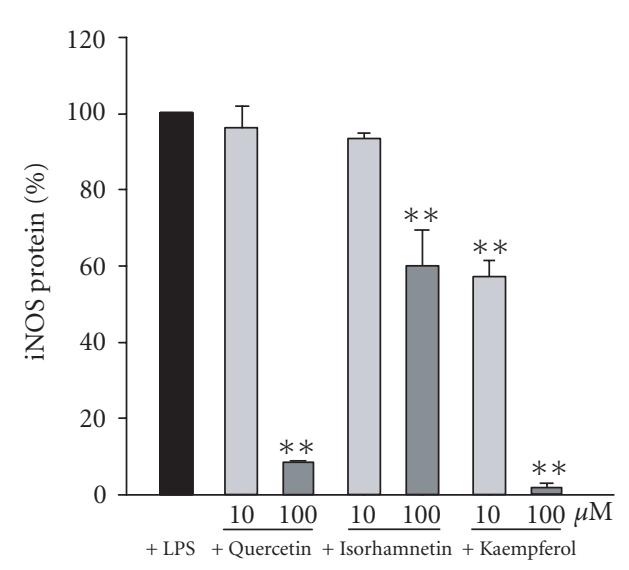

(b)

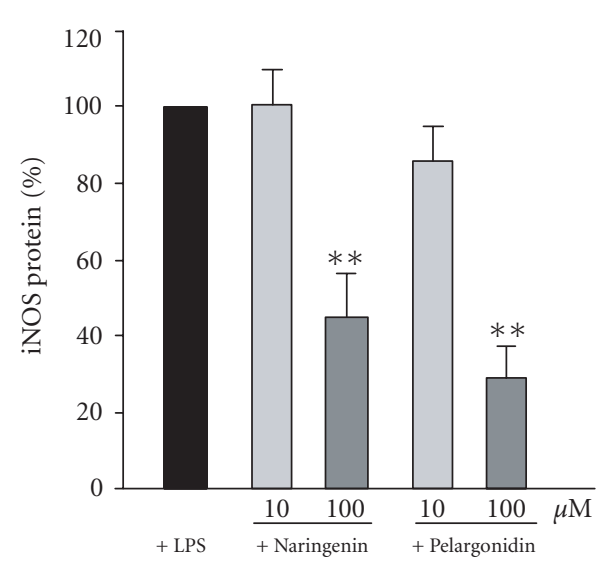

(c)

FIGURE 3: (a) Effects of flavone, daidzein, and genistein on LPS $(100 \mathrm{ng} / \mathrm{ml})$-induced iNOS protein expression in J774 cells during a 24-hour incubation time. (b) Effects of quercetin, isorhamnetin, and kaempferol on LPS $(100 \mathrm{ng} / \mathrm{ml})$-induced iNOS protein expression in J774 cells during a 24-hour incubation time. (c) Effects of naringenin and pelargonidin on LPS (100 ng/ml)-induced iNOS protein expression in J774 cells during a 24-hour incubation time. iNOS protein expression was detected by Western blot. Mean + SEM, $n=3,{ }^{*} P<.01$.

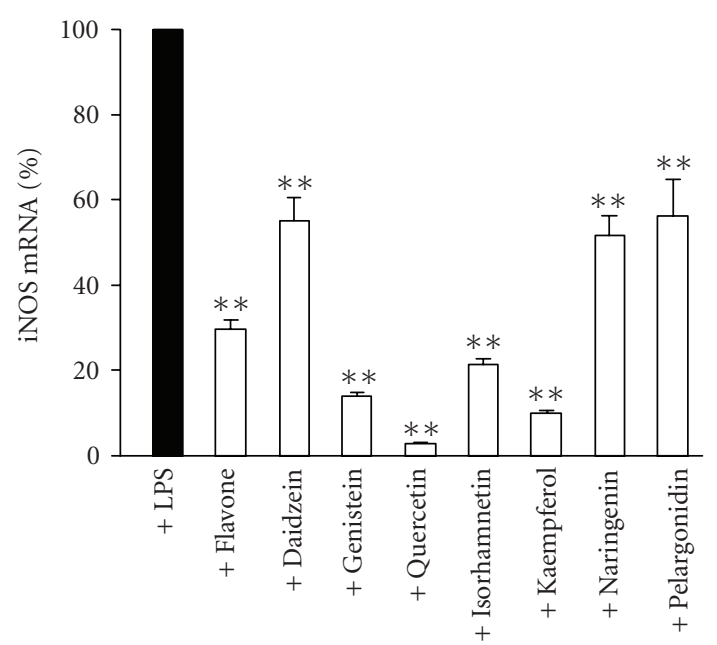

FIGURE 4: Effects of flavonoids on iNOS mRNA expression. Cells were treated with LPS $(100 \mathrm{ng} / \mathrm{ml})$ or with LPS and the tested compound $(100 \mu \mathrm{M})$ and RNA was extracted after 6 hours. iNOS and GAPDH mRNA were measured by real-time RT-PCR and iNOS mRNA levels were normalised against GAPDH. Mean + SEM, $n=$ $3, * * P<.01$.

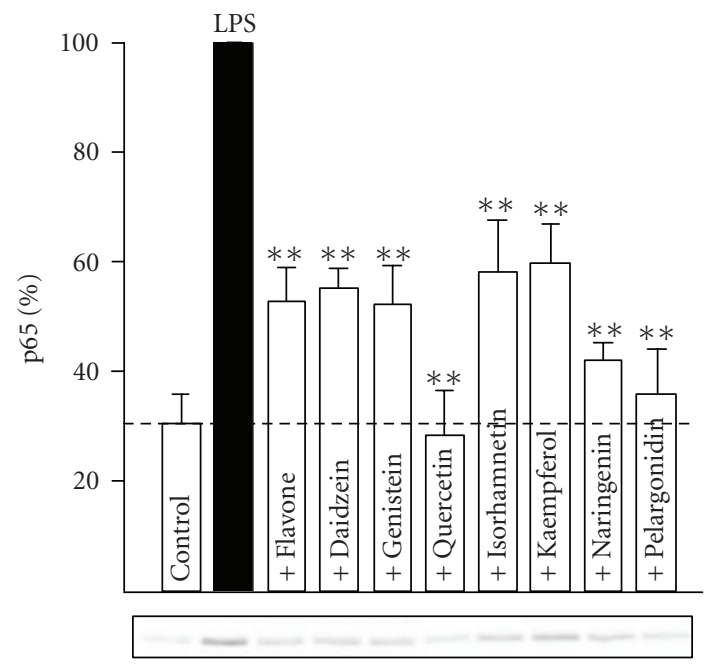

FIGURE 5: Effects of flavonoids on LPS-induced NF- $\kappa$ B activation determined as nuclear translocation of NF- $\kappa$ B. J774 cells were incubated for 30 minutes with LPS $(100 \mathrm{ng} / \mathrm{ml})$ or with LPS and the flavonoid $(100 \mu \mathrm{M})$, and nuclear proteins were extracted. Western blot was used to detect the p65 subunits of NF- $\kappa \mathrm{B}$ in the nuclear extracts. p65 levels in LPS-treated cells were set at 100\% and the other values were related to that. The dotted line represents the nuclear p65 levels in untreated control cells. Mean + SEM, $n=4-6$, ${ }^{* *} P<.01$ as compared to LPS-induced level.

totally (91\% inhibition) inhibited by quercetin. Daidzein, genistein, and kaempferol had a moderate $(32 \%-41 \%$ inhibition) inhibitory effect whereas flavone, isorhamnetin, naringenin, and pelargonidin showed no inhibitory effect on the activation of STAT-1 (see Figure 6). 


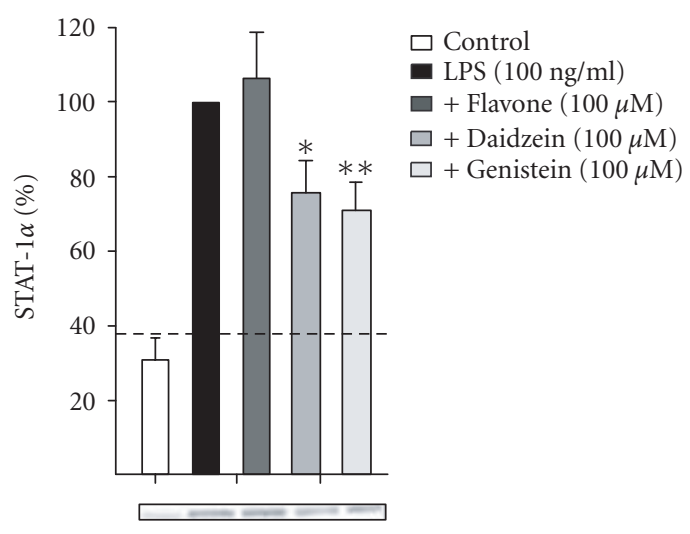

(a)

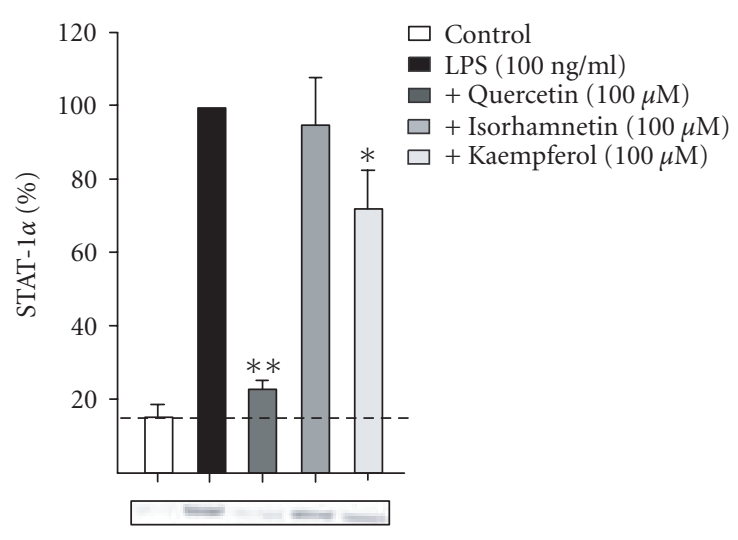

(b)

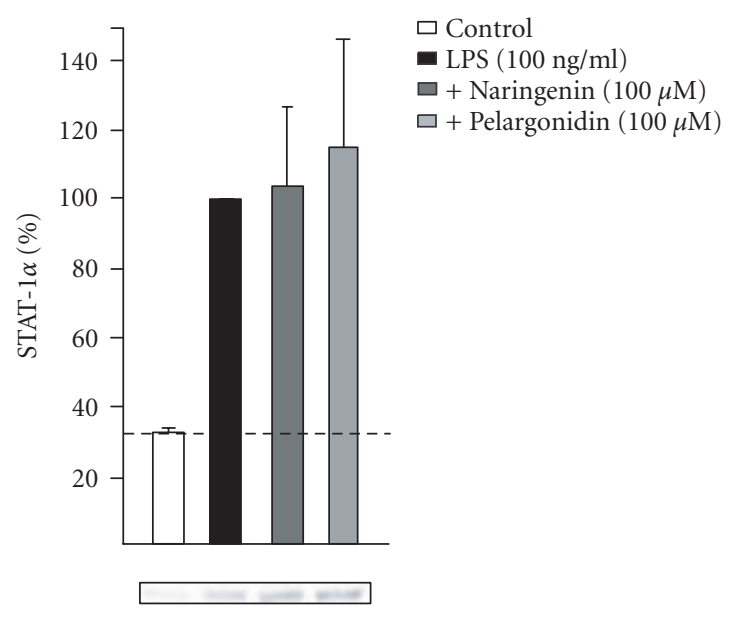

(c)

FIgURE 6: (a)-(c) Effects of flavonoids on LPS-induced STAT-1 activation determined as nuclear translocation of STAT- $1 \alpha$. J774 cells were incubated for 6 hours with LPS $(100 \mathrm{ng} / \mathrm{ml})$ or with LPS and the flavonoid $(100 \mu \mathrm{M})$, and nuclear proteins were extracted. Western blot was used to detect STAT- $1 \alpha$ in the nuclear extracts. STAT$1 \alpha$ levels in LPS-treated cells were set at $100 \%$ and the other values were related to that. The dotted line represents the nuclear STAT- $1 \alpha$ levels in untreated control cells. Mean + SEM, $n=3$, ${ }^{* *} P<.01$, ${ }^{*} P<.05$ as compared to LPS-induced level.

\section{DISCUSSION}

Flavonoids are nonessential dietary factors, and humans consume about $1-2 \mathrm{~g}$ of flavonoids daily. Flavonoids are abundantly present in fruits, vegetables, seeds, nuts, tea, and red wine, and the flavonoid mostly consumed is quercetin. Flavonoids are believed to act as health-promoting substances, and some of them have antioxidant and antiinflammatory properties $[10,11]$. Anti-inflammatory effects have also been found in vivo. For instance, genistein was reported to inhibit LPS-induced septic response in rat [21] and quercetin suppressed experimentally induced arthritis in rat [22].

In the present study, we investigated the effects of flavonoids and related compounds belonging to eight classes (flavones, isoflavones, flavonols, flavanones, flavan-3-ols, anthocyanins, HBA, and HCA) on iNOS expression and NO production in activated macrophages. Eight effective compounds were found. Four compounds (genistein, kaempferol, quercetin, and daidzein) inhibited LPS-induced STAT- 1 and NF- $\kappa$ B activations, and iNOS expression. In addition, four compounds (flavone, isorhamnetin, naringenin, and pelargonidin) inhibited NF- $\kappa$ B activation and iNOS expression but had no effect on STAT-1.

Isoflavones daidzein and genistein inhibited LPS-induced iNOS expression and NO production in a dose-dependent manner, whereas genistin was less effective. Daidzein and genistein also inhibited activations of STAT- 1 and NF- $\kappa$ B, which are important transcription factors for iNOS $[19,20]$. To our knowledge, their effects on STAT- 1 activation have not been reported previously, whereas suppression of DNAbinding of NF- $\kappa$ B by genistein has been reported [23]. Our results confirm earlier observations on the inhibitory effects of daidzein and genistein on iNOS expression and NO production [13, 24-27], and provide a mechanism for the effect through suppression of STAT- 1 and NF- $\kappa$ B activations.

In the flavonol group, isorhamnetin, kaempferol, and quercetin inhibited NO production and iNOS protein and mRNA expression, quercetin and kaempferol being the most potent of the phenolic compounds tested. Isorhamnetin, kaempferol, and quercetin all inhibited NF- $\kappa \mathrm{B}$ activation, and quercetin and kaempferol also had an effect on STAT1 activation. This is the first study to show that isorhamnetin reduces iNOS expression, and that the effect may well be mediated by inhibition of NF- $\kappa$ B activation. Kaempferol has previously been shown to inhibit iNOS expression and NO production $[13,28]$. Here we confirm those findings and show that kaempferol inhibits STAT- 1 and NF- $\kappa$ B activations, which are implicated in their effects on iNOS expression. Chen et al. [29] have reported that quercetin inhibits IFN $\gamma$-induced STAT- 1 activation in mouse BV-2 microglia. In the present study we found that quercetin also suppressed LPS-induced activation of STAT- 1 in macrophages supporting the idea that its effects on STAT-1 are stimulus and celltype independent. Quercetin inhibited LPS-induced STAT-1 activation along with its inhibitory effect on iNOS expression and NF- $\kappa$ B activation. Inhibition of STAT- 1 activation by quercetin is likely involved in the mechanisms by which it inhibits iNOS expression because JAK inhibitors AG-490 
and WHI-P154 have been shown to inhibit iNOS expression along with their suppressive actions on STAT-1 activation $[18,30]$.

Concurring with earlier results, we found flavanone naringenin to inhibit LPS-induced NO production while its glycosylated counterpart naringin had no effect [31]. Our results suggest that the inhibitory effect of naringenin is likely to be at transcriptional level through inhibition of the activation of NF- $\kappa$ B. Pelargonidin has been reported to inhibit NO production in macrophages [26]. Here we extend the data by showing that pelargonidin suppresses NO production by reducing iNOS expression through inhibiting the activation of transcription factor NF- $\kappa \mathrm{B}$.

Regarding the structural requirements of flavonoids for the inhibition of NO production, three main features could be found:

(a) a C-2,3 double bond is a common feature in the six most effective compounds,

(b) a bulky group (e.g., glycoside, rhamnoside, rutinoside, or neohesperidoside) as a substituent lowered or abolished the compound's inhibitory effect (e.g., quercetin was highly effective whereas its rhamnoside-substituted derivative quercitrin was ineffective),

(c) 7 and 4' OH-groups were found in all effective compounds but this alone did not differentiate active from ineffective compounds.

Related structure-activity relationships regarding $\mathrm{PGE}_{2}$ inhibition have been reported in rat peritoneal macrophages [32].

Earlier studies have shown that some flavonoids inhibit NO production in response to inflammatory stimuli $[13,26$, $28,33,34]$. The present study extends the previous knowledge by systematically comparing the effects of a large series of compounds in standardized experimental conditions. Moreover, we investigated the effects of the eight effective compounds not only on NO production but also on iNOS mRNA and protein expression, and on the activation of inflammatory transcription factors NF- $\kappa$ B and STAT- 1 . Some anti-inflammatory flavonoids have been shown to inhibit activation of NF- $\kappa \mathrm{B}$ and the effect has been linked to their antioxidant properties $[29,35]$. Here we found that all the effective compounds (flavone, daidzein, genistein, isorhamnetin, kaempferol, quercetin, naringenin, and pelargonidin) inhibited LPS-induced NF- $\kappa \mathrm{B}$ activation. In addition, genistein, kaempferol, quercetin, and daidzein also inhibited STAT-1 activation. To our knowledge, the inhibitory effects of genistein, kaempferol, and daidzein on STAT-1 activation have not been reported previously, whereas quercetin was found to inhibit IFN $\gamma$-induced activation of STAT-1 in mouse BV-2 microglia [29]. The mechanisms by which genistein, kaempferol, quercetin, and daidzein inhibit STAT-1 activation are not known, but may be associated with inhibition of phosphorylation of STAT-1 or its up-stream kinase JAK2 [36]. Interestingly, the three most potent inhibitors of iNOS expression and NO production, that is, genistein, kaempferol, and quercetin, inhibited both NF- $\kappa$ B and STAT1 activations, whereas those flavonoids inhibiting only NF$\kappa \mathrm{B}$ had a smaller effect on iNOS expression. Because NF- $\kappa \mathrm{B}$ and STAT-1 are involved in the activation of several inflam- matory genes, flavonoids that inhibit activation of NF- $\kappa \mathrm{B}$ and/or STAT-1 are likely to down-regulate production of an array of inflammatory mediators in addition to iNOS. Therefore the present results offer an additional molecular mechanism for the anti-inflammatory action of flavonoids.

In conclusion, we compared the effects of 36 naturally occurring flavonoids and related polyphenolic compounds on LPS-induced NO production and iNOS expression in activated macrophages. The flavonoid classes containing the most effective compounds were isoflavones and flavonols. We identified eight compounds as being able to inhibit LPSinduced NO production and iNOS expression. Four compounds (genistein, kaempferol, quercetin, and daidzein) inhibited activation of both of the important transcription factors for iNOS, that is, STAT- 1 and NF- $\kappa$ B, whereas four compounds (flavone, isorhamnetin, naringenin, and pelargonidin) inhibited only NF- $\kappa$ B. The results partly explain the anti-inflammatory effects of flavonoids.

\section{ACKNOWLEDGMENTS}

The authors wish to thank Mrs Niina Ikonen and Mrs Jaana Tägtström for skilful technical assistance and Mrs Heli Määttä for secretarial help. The study was supported by grants from the Finnish Funding Agency for Technology and Innovation (TEKES), the Medical Research Fund of Tampere University Hospital, Finland, and the Academy of Finland.

\section{REFERENCES}

[1] R. G. Knowles and S. Moncada, "Nitric oxide synthases in mammals," Biochemical Journal, vol. 298, part 2, pp. 249-258, 1994.

[2] W. K. Alderton, C. E. Cooper, and R. G. Knowles, "Nitric oxide synthases: structure, function and inhibition," Biochemical Journal, vol. 357, part 3, pp. 593-615, 2001.

[3] R. Korhonen, A. Lahti, H. Kankaanranta, and E. Moilanen, "Nitric oxide production and signaling in inflammation," Current Drug Targets, vol. 4, no. 4, pp. 471-479, 2005.

[4] E. Moilanen, B. J. R. Whittle, and S. Moncada, "Nitric oxide as a factor of inflammation," in Inflammation: Basic Principles and Clinical Correlates, J. I. Gallin and R. Snyderman, Eds., pp. 787-801, Lippincott Williams \& Wilkins, Philadelphia, Pa, USA, 1999.

[5] C. Bogdan, "Nitric oxide and the immune response," Nature Immunology, vol. 2, no. 10, pp. 907-916, 2001.

[6] J. R. Connor, P. T. Manning, S. L. Settle, et al., "Suppression of adjuvant-induced arthritis by selective inhibition of inducible nitric oxide synthase," European Journal of Pharmacology, vol. 273, no. 1-2, pp. 15-24, 1995.

[7] J.-P. Pelletier, D. Jovanovic, J. C. Fernandes, et al., "Reduced progression of experimental osteoarthritis in vivo by selective inhibition of inducible nitric oxide synthase," Arthritis \& Rheumatism, vol. 41, no. 7, pp. 1275-1286, 1998.

[8] S. M. Evans and B. J. R. Whittle, "Interactive roles of superoxide and inducible nitric oxide synthase in rat intestinal injury provoked by non-steroidal anti-inflammatory drugs," European Journal of Pharmacology, vol. 429, no. 1-3, pp. 287-296, 2001. 
[9] P. Vallance and J. Leiper, "Blocking NO synthesis: how, where and why?" Nature Reviews Drug Discovery, vol. 1, no. 12, pp. 939-950, 2002.

[10] E. Middleton Jr., C. Kandaswami, and T. C. Theoharides, "The effects of plant flavonoids on mammalian cells: implications for inflammation, heart disease, and cancer," Pharmacological Reviews, vol. 52, no. 4, pp. 673-751, 2000.

[11] B. H. Havsteen, "The biochemistry and medical significance of the flavonoids," Pharmacology and Therapeutics, vol. 96, no. 23, pp. 67-202, 2002.

[12] Y.-L. Lin and J.-K. Lin, “(-)-Epigallocatechin-3-gallate blocks the induction of nitric oxide synthase by down-regulating lipopolysaccharide-induced activity of transcription factor nuclear factor- $\kappa$ B," Molecular Pharmacology, vol. 52, no. 3, pp. 465-472, 1997.

[13] Y.-C. Liang, Y.-T. Huang, S.-H. Tsai, S.-Y. Lin-Shiau, C.-F. Chen, and J.-K. Lin, "Suppression of inducible cyclooxygenase and inducible nitric oxide synthase by apigenin and related flavonoids in mouse macrophages," Carcinogenesis, vol. 20, no. 10, pp. 1945-1952, 1999.

[14] H. Kim, Y. S. Kim, S. Y. Kim, and K. Suk, "The plant flavonoid wogonin suppresses death of activated C6 rat glial cells by inhibiting nitric oxide production," Neuroscience Letters, vol. 309, no. 1, pp. 67-71, 2001.

[15] L. C. Green, D. A. Wagner, J. Glogowski, P. L. Skipper, J. S. Wishnok, and S. R. Tannenbaum, "Analysis of nitrate, nitrite, and $\left[{ }^{15} \mathrm{~N}\right]$ nitrate in biological fluids," Analytical Biochemistry, vol. 126, no. 1, pp. 131-138, 1982.

[16] A. Lahti, O. Sareila, H. Kankaanranta, and E. Moilanen, "Inhibition of p38 mitogen-activated protein kinase enhances c-Jun $\mathrm{N}$-terminal kinase activity: implication in inducible nitric oxide synthase expression," BMC Pharmacology, vol. 6, no. 1, p. 5, 2006.

[17] M. M. Bradford, "A rapid and sensitive method for the quantitation of microgram quantities of protein utilizing the principle of protein dye binding," Analytical Biochemistry, vol. 72, no. 1-2, pp. 248-254, 1976.

[18] O. Sareila, R. Korhonen, O. Kärpänniemi, R. Nieminen, H. Kankaanranta, and E. Moilanen, "JAK inhibitors AG-490 and WHI-P154 decrease IFN- $\gamma$-induced iNOS expression and NO production in macrophages," Mediators of Inflammation, vol. 2006, no. 2, Article ID 16161, 7 pages, 2006.

[19] Q.-W. Xie, Y. Kashiwabara, and C. Nathan, "Role of transcription factor NF- $\kappa \mathrm{B} / \mathrm{Rel}$ in induction of nitric oxide synthase," Journal of Biological Chemistry, vol. 269, no. 7, pp. 4705-4708, 1994.

[20] J. Gao, D. C. Morrison, T. J. Parmely, S. W. Russell, and W. J. Murphy, "An interferon- $\gamma$-activated site (GAS) is necessary for full expression of the mouse iNOS gene in response to interferon- $\gamma$ and lipopolysaccharide," Journal of Biological Chemistry, vol. 272, no. 2, pp. 1226-1230, 1997.

[21] H. Ruetten and C. Thiemermann, "Effects of tyrphostins and genistein on the circulatory failure and organ dysfunction caused by endotoxin in the rat: a possible role for protein tyrosine kinase," British Journal of Pharmacology, vol. 122, no. 1, pp. 59-70, 1997.

[22] M. Mamani-Matsuda, T. Kauss, A. Al-Kharrat, et al., "Therapeutic and preventive properties of quercetin in experimental arthritis correlate with decreased macrophage inflammatory mediators," Biochemical Pharmacology, vol. 72, no. 10, pp. 1304-1310, 2006.

[23] A. R. Kim, J. Y. Cho, Y. Zou, J. S. Choi, and H. Y. Chung, "Flavonoids differentially modulate nitric oxide production pathways in lipopolysaccharide-activated RAW264.7 cells,"
Archives of Pharmacal Research, vol. 28, no. 3, pp. 297-304, 2005.

[24] H. Sadowska-Krowicka, E. E. Mannick, P. D. Oliver, et al., "Genistein and gut inflammation: role of nitric oxide," Proceedings of the Society for Experimental Biology and Medicine, vol. 217, no. 3, pp. 351-357, 1998.

[25] F. Sheu, H.-H. Lai, and G.-C. Yen, "Suppression effect of soy isoflavones on nitric oxide production in RAW 264.7 macrophages," Journal of Agricultural and Food Chemistry, vol. 49, no. 4, pp. 1767-1772, 2001.

[26] J. Wang and G. Mazza, "Inhibitory effects of anthocyanins and other phenolic compounds on nitric oxide production in LPS/IFN- $\gamma$-activated RAW 264.7 macrophages," Journal of Agricultural and Food Chemistry, vol. 50, no. 4, pp. 850-857, 2002.

[27] L. S. Scuro, P. U. Simioni, D. L. Grabriel, et al., "Suppression of nitric oxide production in mouse macrophages by soybean flavonoids accumulated in response to nitroprusside and fungal elicitation," BMC Biochemistry, vol. 5, no. 1, p. 5, 2004.

[28] G. Autore, L. Rastrelli, M. R. Lauro, et al., "Inhibition of nitric oxide synthase expression by a methanolic extract of Crescentia alata and its derived flavonols," Life Sciences, vol. 70, no. 5, pp. 523-534, 2001.

[29] J.-C. Chen, F.-M. Ho, P.-D. L. Chao, et al., "Inhibition of iNOS gene expression by quercetin is mediated by the inhibition of $\mathrm{I} \kappa \mathrm{B}$ kinase, nuclear factor- $\kappa \mathrm{B}$ and STAT1, and depends on heme oxygenase-1 induction in mouse BV-2 microglia," European Journal of Pharmacology, vol. 521, no. 1-3, pp. 9-20, 2005.

[30] T. Salonen, O. Sareila, U. Jalonen, H. Kankaanranta, R. Tuominen, and E. Moilanen, "Inhibition of classical PKC isoenzymes downregulates STAT1 activation and iNOS expression in LPStreated murine J774 macrophages," British Journal of Pharmacology, vol. 147, no. 7, pp. 790-799, 2006.

[31] H.-Y. Lin, S.-C. Shen, and Y.-C. Chen, "Anti-inflammatory effect of heme oxygenase 1: glycosylation and nitric oxide inhibition in macrophages," Journal of Cellular Physiology, vol. 202, no. 2, pp. 579-590, 2005.

[32] Y. Takano-Ishikawa, M. Goto, and K. Yamaki, "Structureactivity relations of inhibitory effects of various flavonoids on lipopolysaccharide-induced prostaglandin $\mathrm{E}_{2}$ production in rat peritoneal macrophages: comparison between subclasses of flavonoids," Phytomedicine, vol. 13, no. 5, pp. 310-317, 2006.

[33] H. K. Kim, B. S. Cheon, Y. H. Kim, S. Y. Kim, and H. P. Kim, "Effects of naturally occurring flavonoids on nitric oxide production in the macrophage cell line RAW 264.7 and their structure-activity relationships," Biochemical Pharmacology, vol. 58, no. 5, pp. 759-765, 1999.

[34] G. M. Raso, R. Meli, G. Di Carlo, M. Pacilio, and R. Di Carlo, "Inhibition of inducible nitric oxide synthase and cyclooxygenase-2 expression by flavonoids in macrophage J774A.1," Life Sciences, vol. 68, no. 8, pp. 921-931, 2001.

[35] G. K. Rangan, Y. Wang, Y.-C. Tay, and D. C. Harris, "Inhibition of NF $\kappa$ B activation with antioxidants is correlated with reduced cytokine transcription in PTC," American Journal of Physiology, vol. 277, no. 5, part 2, pp. F779-F789, 1999.

[36] T. Akiyama, J. Ishida, S. Nakagawa, et al., "Genistein, a specific inhibitor of tyrosine-specific protein kinases," Journal of Biological Chemistry, vol. 262, no. 12, pp. 5592-5595, 1987. 




The Scientific World Journal
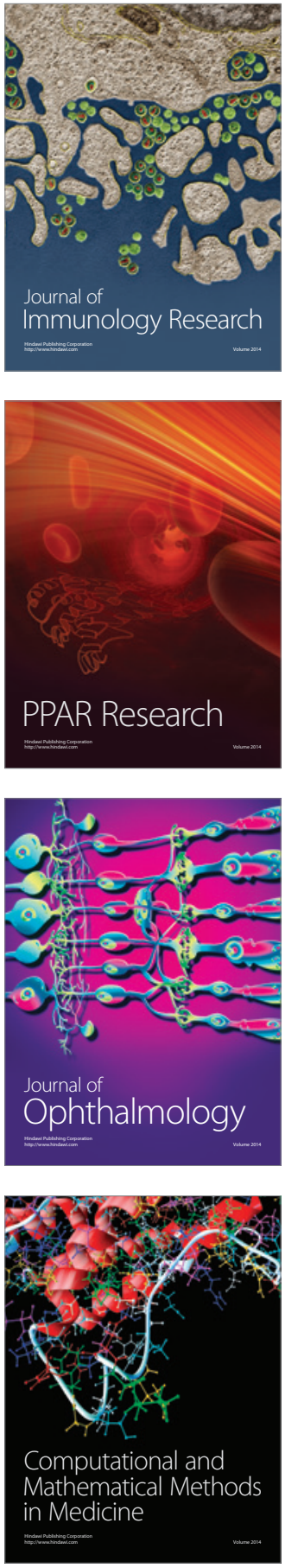

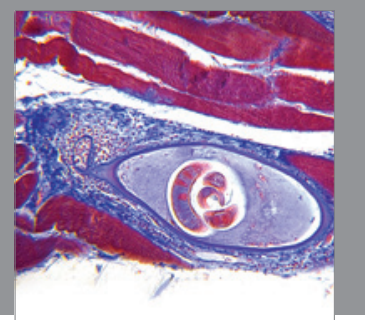

Gastroenterology

Research and Practice
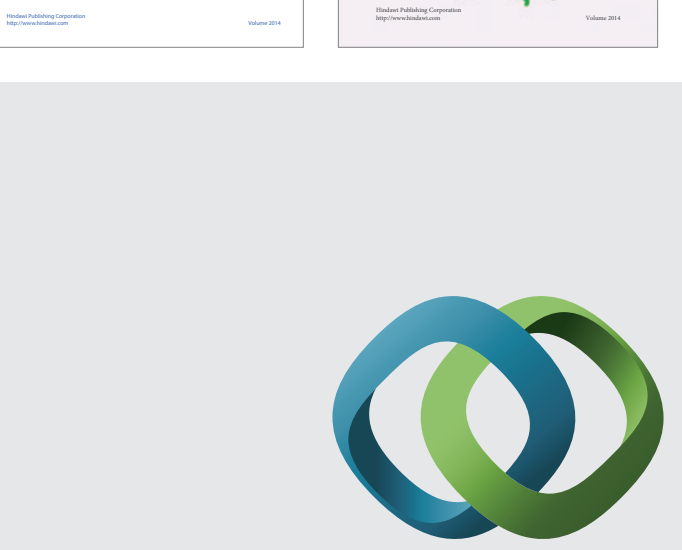

\section{Hindawi}

Submit your manuscripts at

http://www.hindawi.com


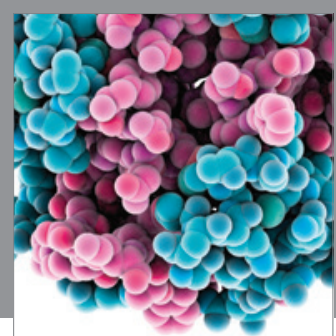

Journal of
Diabetes Research

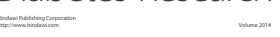

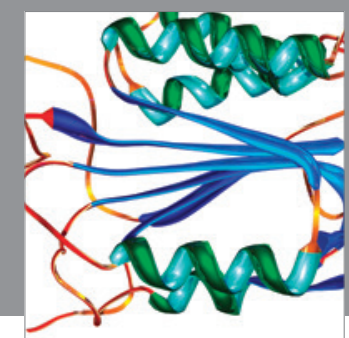

Disease Markers
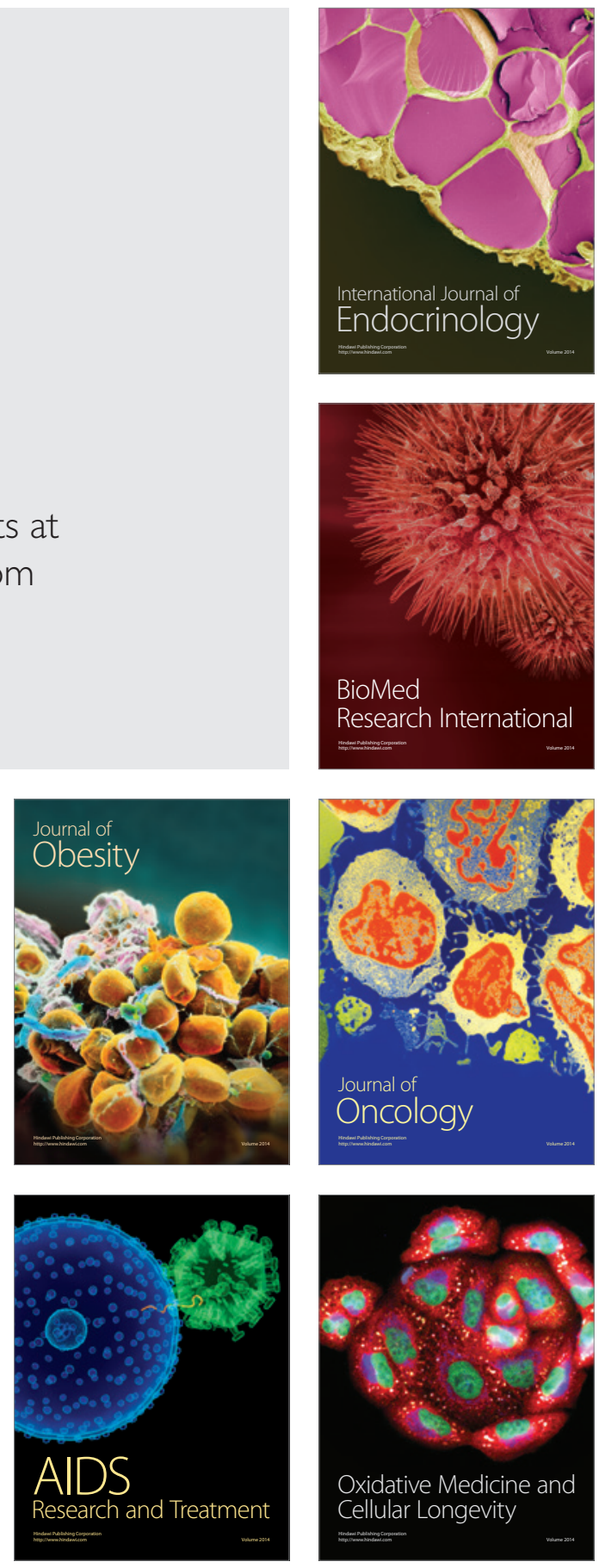